\title{
The effects of executive constraints on political trust
}

\author{
Kursat Cinar (D) and Meral Ugur-Cinar (D) \\ ${ }^{a}$ Department of Political Science \& Public Administration, Middle East Technical University, Ankara, \\ Turkey; ${ }^{\text {DD }}$ epartment of Political Science \& Public Administration, Bilkent University, Ankara, Turkey
}

\begin{abstract}
This article explores political trust, delving into its subcomponents and the relationship between them. It is interested in explaining why governmental trust and trust in regulative state institutions are similar in some countries and different in others. It argues that the variation can best be explained by checks on the executive. This is the case because the more restricted the executive, the less regulative state institutions are affected by the fluctuations in governmental trust. When the government cannot encroach upon state institutions, the impartiality and efficacy of regulative institutions are maintained. The less governmental interference to regulative state institutions, the more such institutions will be devoted to the public rather than partisan interests, resulting in a wider gap between state and government trust. The argument is tested through an empirical analysis of a crossnational panel data based on all existing waves of the World Values Survey.
\end{abstract}

ARTICLE HISTORY Received 7 February 2018; Accepted 21 June 2018

KEYWORDS political trust; checks and balances; executive constraints; democracies; world values survey

\section{Introduction}

As rising numbers of citizens feel estranged from politics, popular confidence in political institutions seems to be lower than ever. ${ }^{1}$ The growing disconnect between the governed and the established political institutions and the alienation of the citizenry from the political realm manifest themselves in decreased voter turnout, drop in party membership, weakening of party loyalties, and the rise of extremist, anti-establishment protest politicians and parties. ${ }^{2}$

Many scholars find diminishing levels of political trust alarming as effective policymaking, engagement in moral civic behaviour, cohesion of society, and the legitimacy and stability of democratic regimes strongly depend on citizens' support for political institutions. ${ }^{3}$ As van der Meer and Dekker maintain, "political trust functions as the glue that keeps the system together and as the oil that lubricates the policy machine". Those who are more optimistic see low political trust as an expression of a healthy democratic attitude of postmaterialist individuals who question political authority. ${ }^{5}$

However one interprets the trends in political trust, an in-depth analysis of the subject matter shows an immense richness in variation within and across country 
cases that warrants further research. People usually express more trust in regulative state institutions than in the partisan incumbents of representative political offices, especially the government. This divergence in trust is higher in some countries, and lower in others. This study is especially interested in understanding what explains these variations.

It is our hypothesis that the more a government is limited in influencing other state institutions, the less it will affect the trust in regulative state institutions. Thus, we hold that the more constrained the executive, the less trust in regulative state institutions will be affected by fluctuations in government trust. By regulative state institutions, we mean public institutions providing vital regulatory services such as justice, public goods and services, and law and order; the judiciary, civil services, and the police being the most characteristic of them. We substantiate this argument through an empirical analysis of a large cross-national panel data based on all existing waves of the World Values Survey (WVS).

\section{Political trust: its conceptualization and subcomponents}

Before proceeding further, we need to clearly define political trust and specify its subcomponents. In general, "political trust" can be defined as the expectation that political institutions (be they representative or regulative) operate according to fair rules without continuous scrutiny. ${ }^{6}$ The trustworthiness of political institutions is a function of their ability to provide citizens with a political atmosphere which ensures political rights and fair participation, to live up to ethical, fair, and transparent standards, and to offer decent public services and economic affluence for the society. ${ }^{7}$

Studies that explore political trust tend to integrate various measures of trust in different political institutions to come up with a single trust index. In general, "political trust" is measured as an additive index of several items evaluating confidence in the parliament, political parties, government, civil services, judiciary, and security forces (police and/or military). ${ }^{8}$ Scholars generally use principal component analysis to support their claims that a single "political trust" indicator can explain variations of trust vested in different political institutions.

For instance, Norris combines trust in parliament, civil services, the legal system, the police, and the army in a principal component analysis to offer a single measure of institutional confidence. ${ }^{9}$ The Cronbach's alpha of this integrated index, which shows the inter-correlation among the five subcomponents of trust is 0.75 , which is at an acceptable level, though not good or excellent according to common thresholds of the principal component analysis. ${ }^{10}$ Later studies such as Hakhverdian and Mayne and Hooghe and Marien produce composite indices of political trust, whose Cronbach's alphas exceed $0.8 .^{11}$ While using composite indices of political trust is convenient and straightforward, this may lead to measurement errors about the concept at hand and thus produce spurious results. ${ }^{12}$ Actual data for a wide array of countries over time show us that trust levels differ considerably for different political institutions. ${ }^{13}$ Citizens distinguish between different objects of political trust ${ }^{14}$ and have different levels of trust vested in civil services, the judiciary, the police, political parties, politicians, the government, and so on. Specifically, scholars find that unidimensional measures and models of political trust which try to integrate all of these political institutions have measurement validity and equivalence issues, in which trust perceptions in representative political institutions such as the government, parliament and political parties tend to differ 
from regulative state institutions such as the judiciary and the police. ${ }^{15}$ In an exemplary study, Denters et al. show that there are on average higher levels of trust in regulative state institutions in European countries regardless of the overall level of trust. ${ }^{16}$ In a similar vein, Torcal argues that trust in judicial institutions has hardly declined in most European countries, while there has been a significant decline in representative political institutions (parliaments, political parties), claiming that this is a symptom of a representation crisis but not a crisis of the rule of law. ${ }^{17}$

We argue that there is a crucial distinction in levels of political trust between governmental and regulative state institutions. Generally speaking, governmental trust, on the one hand, hinges on citizens' evaluations of institutional performance that the government yields good political and economic outcomes such as promoting growth, governing effectively, and avoiding corruption. To this end, governmental authorities that do not perform well generate distrust; political authorities that perform well produce trust. ${ }^{18}$ In light of Easton's canonical work, governmental trust usually refers to the "specific support" which deals with citizens' satisfaction with and evaluation of the incumbent party's performance at a particular time period. ${ }^{19}$ On the other hand, regulative state institutions (the judiciary, the police, civil services) which offer citizens crucial regulatory services such as justice, public goods and services, and law and order, are generally perceived differently by the people. ${ }^{20}$ In Eastonian terms, trust vested in these regulative state institutions usually corresponds to "diffuse support", which is more related to a deep-seated set of attitudes towards political institutions. ${ }^{21}$

Some scholars suggest that a continuous decline in specific governmental trust may have detrimental spillover effects on trust vested in other political institutions, including regulative state institutions over time. ${ }^{22}$ Yet, the different nature of trust for these different political institutions calls for a distinction between governmental versus regulative state institutions. Few studies on political trust make a distinction between these institutions. In an exceptional study, Zmerli successfully differentiates governmental and regulative state institutions and offers insights about the origins of trust in these institutions. However, the scope of that study is limited to Europe and thus it fails to offer wider interpretations that would apply to cases outside Europe. ${ }^{23}$ Moreover, it does not provide in-depth explanations how and why different subcomponents of political trust covary or diverge and how this relates to the overarching concept of political trust in general. In this article, we address these limitations and aim to offer novel contributions to the study of political trust by offering a global-scale analysis for several points in time and underlining the crucial role that executive constraints play in determining the levels of public trust vested in political institutions. We use our independent variable to show how trust in regulative state institutions and in government diverge or converge based on the level of executive constraints in democratic societies.

\section{Empirical analysis}

To explore the factors behind public trust vested in governmental and regulative state institutions and the circumstances under which governmental trust and state trust differ, we utilize WVS data. We analyse public opinion data from all of the six waves of WVS, ensuring a coverage of 73 democratic nations between 1981 and $2014 .{ }^{24}$ To determine the trust level of each country for each WVS wave, we take the sum total 
of the percentage of respondents who state that they trust governmental and regulative state institutions "a great deal" and "quite a lot" in the WVS waves. ${ }^{25}$

The article takes into account public opinion data for democratic and semi-democratic countries only and disregards data for authoritarian nations. There are several reasons why it does so. First, political trust is interpreted and evaluated differently under authoritarian and democratic political settings. ${ }^{26}$ While political trust may mostly refer to the evaluation of transparency and participation in democratic settings it might rather refer to efficacy and satisfaction with service delivery under authoritarianism. ${ }^{27}$ This discrepancy makes data produced in these different political settings non-comparable cross-nationally. ${ }^{28}$ Moreover, some scholars highlight rampant levels of clientelistic relations in authoritarian regimes as compared to higher levels of programmatic policies in democratic countries. ${ }^{29}$ These scholars argue that extensive clientelism in authoritarian regimes is behind ostensibly high levels of political trust. ${ }^{30}$ Finally, one of the most crucial reasons why we disregard authoritarian nations is "preference falsification", which refers to the sociopolitical situations in which people deliberately misrepresent their genuine views under perceived social and political pressures. $^{31}$ Preference falsification is particularly pervasive in authoritarian regimes, ${ }^{32}$ where people refrain from stating their sincere political views out of fear of punishment. ${ }^{33}$ In a study that investigates public opinion data on governmental and state trust, it is very likely that people in authoritarian countries would deliberately conceal their views, which could lead to spurious results in empirical analyses. To this end, the article takes into account data for countries that are considered as at least "partly free" by Freedom House. ${ }^{34}$ If a country under analysis has transitioned from being a "partly free" state to "not free" (or vice versa), the article includes data only for the time period when the country is deemed "partly free" - and not the period when it is seen as "not free" - due to the reasons elaborated above. ${ }^{35}$ This ensures maximum coverage of countries and time periods, which enhances generalizability and comparability.

Our concept of "regulative state institutions" includes the judiciary, the civil services, and the police. We create a composite variable of trust for regulative state institutions based on principal component analysis. The subcomponents of trust in regulative state institutions are trust vested in the judiciary, the civil services, and the police. In light of our panel dataset, principal component analysis shows that all of the three subcomponents load strongly on our trust in regulative state institutions indicator (factor loadings for the judiciary, the civil services, and the police are $0.88,0.70,0.72$ ) and have a Cronbach's alpha of 0.82 . While making the crucial distinction between trust in regulative state institutions and trust in governmental institutions, this statistically successful and theoretically sound composite index ensures that we conduct several comparisons between these two concepts for democratic countries throughout the world.

A comparison of trust in regulative state institutions and trust in governmental institutions based on the WVS data (1981-2014) reveals interesting insights. As shown in Table 1, we rank all of the country-level observations in several WVS waves based on the difference between trust in regulative state institutions and governmental institutions. Out of the top 10 states for the difference variable, nine are established democracies whereas only Nigeria is a partially free country. Out of the bottom 10, five countries (Ecuador, Guatemala, Venezuela, Bangladesh, Peru) were non-consolidated democracies at the time of the respective WVS surveys. Out of the remaining five countries, which are considered fully democratic, some have a history of authoritarian 
Table 1. Country rankings based on the difference between trust in regulative state and governmental institutions (top 10 and bottom 10 ).

\begin{tabular}{|c|c|c|c|c|c|c|c|c|c|}
\hline Top 10 & Country & $\begin{array}{l}\text { Trust in regulative } \\
\text { institutions }\end{array}$ & $\begin{array}{l}\text { Trust in governmental } \\
\text { institutions }\end{array}$ & Difference & Bottom 10 & Country & $\begin{array}{l}\text { Trust in regulative } \\
\text { institutions }\end{array}$ & $\begin{array}{l}\text { Trust in governmental } \\
\text { institutions }\end{array}$ & Difference \\
\hline 1 & Nigeria (1994) & 60.9 & 26.1 & 34.8 & 10 & Mexico (2009) & 31.5 & 43.9 & -12.4 \\
\hline 2 & New Zealand (1999) & 49.7 & 15.2 & 34.5 & 9 & India (2004) & 36.0 & 48.5 & -12.5 \\
\hline 3 & Japan (2014) & 57.9 & 24.3 & 33.6 & 8 & Bulgaria (1999) & 41.9 & 56.0 & -14.1 \\
\hline 4 & Germany (1999) & 56.9 & 23.5 & 33.4 & 7 & Ecuador (2014) & 34.5 & 50.4 & -15.9 \\
\hline 5 & Australia (2014) & 61.6 & 30.0 & 31.6 & 6 & Guatemala (2009) & 20.0 & 36.1 & -16.1 \\
\hline 6 & Finland (1999) & 62.0 & 31.0 & 31.0 & 5 & Venezuela (2004) & 39.1 & 55.7 & -16.6 \\
\hline 7 & Hungary (2009) & 47.4 & 16.4 & 31.0 & 4 & Bangladesh (1999) & 59.8 & 77.2 & -17.4 \\
\hline 8 & Italy (2009) & 55.6 & 25.8 & 29.8 & 3 & Uruguay (2009) & 43.3 & 60.7 & -17.4 \\
\hline 9 & Canada (2009) & 65.6 & 36.7 & 28.9 & 2 & Argentina (2009) & 16.3 & 36.9 & -20.6 \\
\hline 10 & South Korea (2004) & 56.4 & 28.9 & 27.5 & 1 & Peru (1999) & 15.8 & 37.0 & -21.2 \\
\hline
\end{tabular}

Notes: The numbers in parentheses after country names show the WVS date. Source: World Values Survey. 
hegemonic parties (Mexico) or series of military coups (Argentina, Uruguay), some have transitioned to democracy from communism after the end of the Cold War era (Bulgaria). All in all, the difference between trust in regulative state institutions and trust in governmental institutions seems to diverge as the countries get more democratic. But what is the underlying reason(s) behind this situation?

To better understand the dynamics behind the (co-)variations in different components of political trust, we have grouped the countries in our sample based on their level of democracy under the categories of partly free or free states at the time of the WVS ( $n_{1}=57$ and $n_{2}=114$ respectively). Statistical analyses show that the correlation between trust in regulative state institutions and governmental trust for partly free states is 0.71 whereas this correlation drops to 0.57 for free states (overall correlation for the whole sample is 0.62 ). In other words, different components of political trust start to diverge as countries get more democratic, leading to a 0.14 drop in correlation between regulative trust and governmental trust. Furthermore, means-difference tests for trust in regulative state institutions and governmental trust show us that these two figures do not differ significantly enough for partly free states whereas they do differ very significantly for free states ( $t$-stat for this test is 4.56 and $p$ is 0.00 ). These preliminary analyses show how trust in regulative state institutions and governmental trust start to be perceived differently as countries get more democratic whereas they are not as distinguishable in partly free states.

We argue that the reason behind the different correlation levels of government trust and trust in regulative state institutions can best be explained by the variation in the level of checks on the executive. We claim that the more the executive is restricted, the less regulative state institutions are affected by the fluctuations in governmental trust. Since in countries with better-established checks and balances the government cannot encroach upon state institutions, the impartiality and efficacy of these regulative institutions are maintained. The more insular the state from government, the more such institutions will be devoted to the public rather than the partisan base of the government, resulting in a wider gap between state trust and government trust. On the other hand, citizens would tend to conflate different public institutions in systems lacking proper checks and balances. Furthermore, higher interventions by politicians in governmental offices on civil services will result in biased and inferior results, which would eradicate people's trust vested in regulative state institutions.

We instrumentalize "executive constraints" with the "liberal component index" (v2x_liberal) in the Varieties of Democracy (V-Dem) dataset. ${ }^{36}$ This variable aims to capture to what extent the ideal of liberal democracy is achieved. Particularly, it judges the quality of democracy by the extent of protection of individual rights and liberties against the tyranny of the state and the limits placed on government. As Coppedge et al. maintain, the liberal component index controls for "constitutionally protected civil liberties, strong rule of law, an independent judiciary, and effective checks and balances that, together, limit the exercise of executive power" ${ }^{37}$ This is a continuous interval variable that ranges between 0 and 1,1 referring to the highest level of executive constraints.

We first conduct bivariate regressions with our executive checks variable as the independent variable and the regulative state trust, governmental trust, and differential trust (regulative trust minus governmental trust) variables as dependent variables in separate regressions. As shown in Figure 1, there is a strong positive relationship between executive constraints and trust in regulative state institutions $(p=0.02)$. On the other hand, 


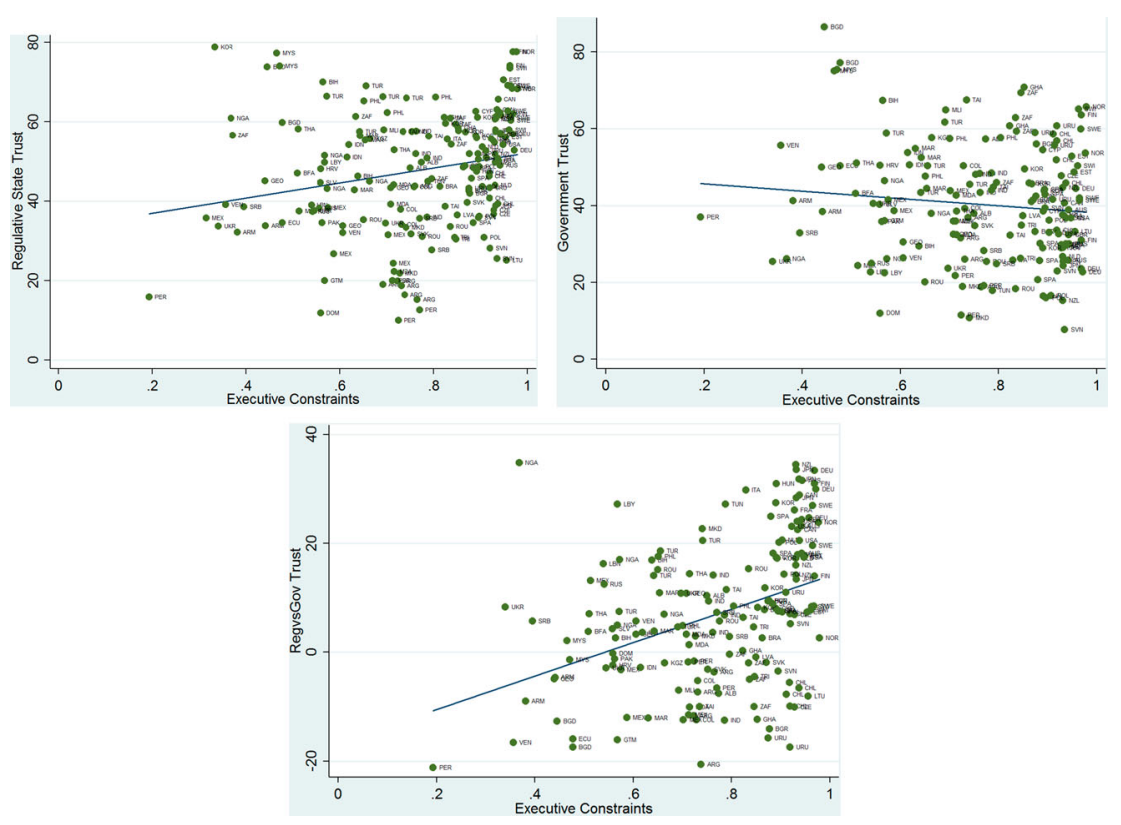

Figure 1. Relationship between executive constraints and political trust variables.

the executive constraints variable is negatively correlated with governmental trust. However, this correlation is only significant at $10 \%(p=0.09)$. The strongest relationship between our checks and balances variables and political trust indicators is found between our independent variable and the difference variable ("regvsgov" variable). Indeed, this relationship is highly statistically significant $(t=4.58 ; p=0.00)$. This means that with a higher level of checks and balances on the executive branch, the trust levels vested in regulative state institutions and governmental institutions start to diverge. Inclusion of multiple control variables to our analysis reveals further insights.

One of the factors to be taken into account while examining the level of political trust in a country is the state of the economy. The existing literature finds that people tend to trust less in their political institutions when the national economy is in decline whereas they tend to trust more when the economy is performing well. ${ }^{38}$ Since fluctuations and the state of macroeconomic performance are more tied to the incumbent government performance, ${ }^{39}$ we expect the greatest impact of the state of the economy to be on governmental trust. In other words, we expect to find a positive relationship between macroeconomic performance and political trust, especially governmental trust. We instrumentalize macroeconomic performance by the annual gross domestic product (GDP) growth (based on constant 2010 US dollars in the World Bank 2017 dataset). Higher GDP growth is expected to increase political trust whereas economic contractions should lead to decline in political trust.

Another macroeconomic factor to be considered is the level of inequality. Scholars argue that growing levels of inequality can diminish levels of political trust. ${ }^{40}$ On the other hand, as Freitag and Bühlmann maintain, "greater income equality and increased activity by the state in promoting equal opportunities promote trust". ${ }^{41}$ To this end, 
countries in which institutions of the welfare state reduce income disparities are more likely to be trusted. For instance, people in Scandinavian countries in which the welfare state is created to bring down income inequality tend to trust more in political institutions. ${ }^{42}$ We use the Gini index to account for income inequality. In light of the literature, we expect to find a negative correlation between income inequality and political trust: the higher the Gini coefficient in a country, the lower the political trust should be.

Another important area of research on political trust deals with the impact of education. Some scholars argue that education enhances political trust ${ }^{43}$ whereas others claim that the effect of education is negative. ${ }^{44}$ Some experts in the former camp contend that education has a specifically conditional positive effect on political trust in societies where level of corruption is perceived to be low, such as Denmark, Finland, Germany, Great Britain, and the Netherlands. ${ }^{45}$ Others in the same camp tackle the issue differently and assert that the political arena has increasingly become a domain of highly educated and qualified citizens and alienated the less educated from politics. ${ }^{46}$ On the other hand, the latter group of scholars maintain that with increasing shares of well-educated citizens comes a reflective citizenry that distrusts political institutions. ${ }^{47}$ According to these scholars, political distrust is not some undesirable phenomenon but simply an expression of individual orientations of well-educated and critical citizens. ${ }^{48}$ We measure educational attainment by the widely used "average years of schooling" data by Barro and Lee. ${ }^{49}$

A potentially crucial political factor to bear in mind with regard to political trust is how proportional electoral institutions represent the electorate. Some experts suggest that there is a strong correlation between proportionality of the electoral system and trust vested in political institutions. ${ }^{50}$ These scholars maintain that proportional institutions with greater capacity for power-sharing are more likely to facilitate political trust. ${ }^{51}$ Others argue that majoritarian electoral institutions yield higher political trust ${ }^{52}$ since the attribution of responsibility for policy outcomes is clearer than in proportional institutions. ${ }^{53}$ To measure the impact of electoral systems, we create a dummy variable for majoritarian versus proportional electoral systems (called "elecmaj"), in which 1 refers to countries with majoritarian electoral institutions and 0 to countries with proportional institutions.

Another important political factor to bear in mind regarding political trust is regime type. Some scholars argue that the presidential and parliamentary systems may have different levels of political trust, in which all parties in parliamentary systems have a stake in the policymaking process and thus produce higher levels of trust, compared to the winner-takes-all presidential regimes. ${ }^{54}$ To measure the effect of regime type, we utilize the "TypeExec" variable in Norris's Democracy Time Series Dataset ${ }^{55}$ in which 0 refers to presidential regimes, 1 to assembly-elected presidential regimes, and 2 to parliamentary regimes.

The last institutional variable that we take into account in our model is the distinction between federal versus unitary states. According to Elazar, federal systems should elicit greater political trust than unitary systems since federalism manages to accommodate simultaneously the needs of different regions, and different groups in the electorate, whereas unitary states allow less flexibility and produce more losers from the system. ${ }^{56}$ Likewise, spanning an array of European countries, Anderson et al. illustrate that political trust is higher in federal states. On the other hand, other scholars show that political trust in fact tends to be higher unitary systems. ${ }^{57}$ To measure the impact of this 
distinction, we create a dummy variable ("fedvsunit"), in which 1 refers to unitary states and 0 to federal states.

Finally, we take into account structural and historical factors that may influence political trust. First, we take into consideration the effect of social cleavages. Scholars argue that in countries with salient social cleavages, political trust is affected negatively by polarized segments of the society whereas high trust countries are usually characterized with less salient social cleavages. ${ }^{58}$ We utilize Alesina et al.'s widely cited measure of ethnolinguistic fractionalization to test the effect of social cleavages on political trust. ${ }^{59}$ Moreover, we also factor the impact of historical conditions into our analysis. Specifically, we test whether a history of military coups has an effect on political trust. Experts suggest that, even after their demise, military regimes do leave a huge imprint on the sociopolitical landscape in many countries. ${ }^{60}$ Citizens who live in countries with a history of military coups may have lower confidence vested in political institutions. To test this proposition, we create a military coup variable ("coups"), which is 1 if the country under analysis had a successful military coup and lived under a military regime, and 0 if it has not (For descriptive statistics see Appendix A).

Before we delve into a multivariate analysis, we show simple zero-order correlations between our three trust indices and a range of control variables in order to develop an understanding of the associations between these variables. Table 2 illustrates the basic relationships between our dependent and control variables.

Our dataset is a time-series cross-sectional (TSCS) panel data with observations for multiple countries and multiple years. The extant literature on political trust mostly depends on cross-sectional (typically cross-country) analyses based on a particular point in time. Moving beyond such cross-sectional analyses to TSCS data analyses enables us to study sociopolitical phenomena such as political trust in a broader sense with increased time horizons, address the problems about the assumption of cross-sectional and longitudinal equivalence (that is, drawing longitudinal, time-sensitive comparisons based on cross-sectional analyses). ${ }^{61}$ However, one should be very careful about model selection and specification, paying attention to the potential risks and the nature of the data at hand. ${ }^{62}$ To this end, we first compare the statistical successes of the ordinary least squares (OLS) and random effects (RE) models based on the Breusch-Pagan Lagrange multiplier (LM) test. The test results (Chibar-Square = 8.55 with a $p$-value of 0.0017 ) indicate that we soundly reject the null hypothesis and conclude that the RE model would be more appropriate than the OLS model. Next, we compare the RE model and fixed effects (FE) model. The FE model is argued to be successful in dealing with TSCS data since it allows for a correlation between the

Table 2. Zero-order correlations between political trust variables and control variables.

\begin{tabular}{lccc}
\hline & $\begin{array}{c}\text { Regulative state } \\
\text { institutions }\end{array}$ & $\begin{array}{c}\text { Governmental } \\
\text { institutions }\end{array}$ & $\begin{array}{c}\text { RegvsGov trust } \\
\text { difference }\end{array}$ \\
\hline GDP growth & -0.01 & $0.19^{* * *}$ & $-0.24^{* * * *}$ \\
Gini index & $-0.17^{* *}$ & $0.19^{* *}$ & $-0.42^{* * *}$ \\
Educational attainment & 0.02 & $-0.35^{* * *}$ & $0.44^{* * *}$ \\
Majoritarian electoral institution & -0.01 & 0.01 & -0.01 \\
Regime type & $0.31^{* * *}$ & -0.01 & $0.37^{* * *}$ \\
Federal vs. unitary States & -0.02 & 0.05 & -0.08 \\
Ethnolinguistic fractionalization & $-0.15^{* * *}$ & 0.15 & $-0.35^{* * *}$ \\
Military coup & -0.09 & 0.13 & $-0.26^{* * *}$ \\
\hline
\end{tabular}

Notes: ${ }^{* *}=p<0.05 ;{ }^{* * *}=p<0.01$. 
residuals and the explanatory variables. However, the FE model disregards the effects of time-invariant variables (variables that do not change over time). In our dataset, we have potentially important control variables such as political regime type and federal-unitary dimension that are indeed time-invariant, which would be neglected in an FE model. Based on our dependent and independent variables, we nonetheless run the Hausman test that compares the RE and FE models. The test results (ChiSquare $=2.82$ with a $p$-value over 0.8305 ) fail to reject the null hypothesis. Thus, we prefer the RE model over the FE model as the former model is at least as successful as the latter and it further allows us to incorporate both time-variant factors (such as executive constraints) and time-invariant factors (regime variables, and so on). Finally, to account for the potential problems of heteroskedasticity and autocorrelation, we use clustered standard errors. ${ }^{63}$ Overall, we utilize a random-effects generalized least squares (GLS) model with clustered standard errors against heteroskedasticity and autocorrelation. Based on our model specification and the TSCS data at hand, the coefficients for the independent variables would capture the average effect of the chosen independent variable over the dependent variables (that is, trust variables) across time and between countries (in other words, the coefficients include both within-entity and between-entity effects).

Table 3 shows the results of our statistical tests. This table illustrates how each independent variable is correlated with trust in regulative state institutions and governmental trust, given other control variables. Yet, we are more interested in how different subcomponents of political trust, more specifically trust in regulative state institutions and governmental trust, interact with each other in light of our independent variables. To this end, we draw our main inferences based on our difference variable (trust vested in regulative state institutions minus trust in governmental institutions).

To this end, we observe that our main explanatory variable, the executive constraints variable, accounts for the major divergence between these two trust variables. In other words, with higher checks and balances on the executive branch, people tend to express different levels of trust in regulative state institutions and governmental institutions, in which they usually tend to trust more in the former, rather than the latter. Statistically speaking, one standard deviation increase in our executive constraints variable (that is, 0.22 units) leads to a 3.98-point divergence between regulative state trust and governmental trust. Furthermore, in light of the $t$-scores of all variables in the difference model, we see that the executive constraints variable has the highest $t$-score (2.97), having the highest explanatory power of our independent variables to understand the relationship between different components of political trust.

In light of our difference model, we also observe that higher levels of inequality lead to convergence between regulative state trust and governmental trust as a higher Gini index decreases the difference between these two trust variables. This may mean that people living in unequal societies do not discriminate between different political institutions and hold them equally responsible for income inequalities. In a similar vein, in societies where social cleavages are more salient, citizens are less likely to distinguish between government and administrative institutions. Moreover, statistical tests show us that higher educational attainment leads to lower levels of political trust, both for regulative state institutions and governmental institutions (especially for the latter). However, educational attainment is not statistically significant for the difference variable. This indicates that the impact of education may be mediated by other control variables in the difference model. 
Table 3. Determinants of political trust.

\begin{tabular}{|c|c|c|c|}
\hline & $\begin{array}{c}\text { Regulative state } \\
\text { institutions }\end{array}$ & $\begin{array}{c}\text { Governmental } \\
\text { institutions }\end{array}$ & $\begin{array}{c}\text { RegvsGov trust } \\
\text { difference }\end{array}$ \\
\hline \multirow[t]{3}{*}{ Executive constraints } & -0.75 & -8.81 & $18.11^{* * *}$ \\
\hline & $(4.50)$ & $(9.43)$ & $(6.10)$ \\
\hline & {$[-0.17]$} & {$[-0.93]$} & {$[2.97]$} \\
\hline \multirow[t]{3}{*}{ GDP growth } & 0.07 & 0.19 & -0.15 \\
\hline & $(0.11)$ & $(0.24)$ & $(0.16)$ \\
\hline & {$[0.64]$} & {$[0.81]$} & {$[-0.94]$} \\
\hline \multirow[t]{3}{*}{ Gini index } & -0.06 & 0.12 & $-0.21^{\dagger}$ \\
\hline & $(0.21)$ & $(0.27)$ & $(0.13)$ \\
\hline & {$[-0.28]$} & {$[0.47]$} & {$[-1.60]$} \\
\hline \multirow[t]{3}{*}{ Educational attainment } & -0.81 & $-1.36^{*}$ & 0.74 \\
\hline & $(0.62)$ & $(0.81)$ & $(0.53)$ \\
\hline & {$[-1.30]$} & {$[-1.66]$} & [1.39] \\
\hline \multirow[t]{3}{*}{ Majoritarian vs. proportional electoral institution } & -2.63 & -1.55 & 1.17 \\
\hline & $(2.68)$ & $(2.92)$ & $(2.46)$ \\
\hline & {$[-0.98]$} & {$[-0.53]$} & {$[0.48]$} \\
\hline \multirow[t]{3}{*}{ Regime type (parliamentary vs. presidential regime) } & $3.91^{*}$ & 2.26 & $2.53^{\dagger}$ \\
\hline & $(2.08)$ & $(2.28)$ & $(1.57)$ \\
\hline & {$[1.88]$} & {$[0.99]$} & {$[1.61]$} \\
\hline \multirow[t]{3}{*}{ Federal vs. unitary states } & $-5.39^{\dagger}$ & 2.34 & $-6.06^{* * *}$ \\
\hline & $(3.74)$ & $(3.30)$ & $(2.13)$ \\
\hline & {$[-1.44]$} & {$[0.71]$} & {$[2.84]$} \\
\hline \multirow[t]{3}{*}{ Ethnolinguistic fractionalization } & -8.29 & 11.21 & $-13.61^{* *}$ \\
\hline & (9.54) & $(10.30)$ & $(6.80)$ \\
\hline & {$[-0.87]$} & [1.09] & {$[-2.00]$} \\
\hline \multirow[t]{3}{*}{ Military coups } & -3.94 & -2.53 & 1.34 \\
\hline & $(4.46)$ & $(4.46)$ & $(2.46)$ \\
\hline & {$[-0.88]$} & {$[-0.57]$} & {$[0.55]$} \\
\hline Number of observations & 136 & 126 & 125 \\
\hline Number of countries & 59 & 59 & 59 \\
\hline Average observations per country & 2.3 & 2.1 & 2.1 \\
\hline Overall significance (Wald Chi-Sq) & $14.55^{*}$ & $22.20^{* * *}$ & $149.29 * * *$ \\
\hline R-squared & 0.1440 & 0.1349 & 0.4181 \\
\hline
\end{tabular}

Notes: We use GLS models with clustered standard errors against heteroskedasticity and autocorrelation. Standard errors in parentheses and $t$-scores for individual variable significance in square brackets. ${ }^{* * *}=p<0.01,{ }^{* *}=p<$ $0.05,{ }^{*}=p<0.10 .^{\dagger}=p<0.15$. Majoritarian versus proportional electoral institution $(1=$ majoritarian; $0=$ proportional); Regime type (parliamentary versus presidential regime) $(0=$ presidential; $1=$ assembly-elected presidential; 2 = parliamentary); federal versus unitary states $(1=$ unitary; $0=$ federal). Sources: World Values Survey for trust data; Coppedge et al. (Varieties of Democracy (V-Dem) Project ) for executive constraints; World Bank dataset for GDP growth and Gini indices; Barro and Lee ("A New Data Set of Educational Attainment") for educational attainment; Norris (Democracy Time-series Dataset) for regime type; Alesina et al. ("Fractionalization") for ethnolinguistic fractionalization. We created the remaining variables on our own, based on an extensive review of political systems throughout the world.

Our difference model also points out three important political insights. First, majoritarian and proportional electoral institutions do not make a difference in determining divergent levels of political trust. Second, our regime type variable is positively associated with our difference variable. This shows us that in presidential regimes different political institutions are perceived similarly as the presidential powers seem to have spillover effects on trust vested in the judiciary, the civil services, and the police. In other words, citizens living in presidential regimes tend to trust governmental and regulative state institutions equally. On the other hand, in parliamentary regimes, different subcomponents of political trust diverge as people tend to hold different trust judgements for governmental institutions and regulative state institutions. Finally, the federalunitary distinction also leads to differential trust levels in political institutions. Specifically, the difference variable is affected negatively as a state becomes unitary. This means 
that political institutions in unitary states are more difficult to distinguish, that is people tend to equally weigh regulative state institutions and governmental institutions in unitary states and trust them accordingly. On the other hand, statistical results show us that citizens in federal states tend to differentiate between different political institutions as they show divergent levels of political trust vested in regulative and governmental institutions.

Furthermore, our difference model yields an overall R-Squared figure of 0.4181, which captures both cross-country and over-time variances of trust differentials between regulative state and governmental institutions. Wald test results also show that the difference model is particularly successful (with the highest Wald ChiSquare value) with regard to the overall statistical significance of entire models.

All of these statistical tests help us pinpoint the political, economic, sociological, and historical factors behind different levels of trust vested in different political institutions. Using a difference model is especially illuminating to understand under what circumstances people tend to hold different trust judgements for regulative state institutions and governmental institutions. One of the major findings of these statistical tests is the importance of executive checks on differential trust levels in political institutions. Our analyses show that with higher checks and balances on the executive come different notions and divergent levels of trust for different political institutions. Specifically, notions of "regulative state trust" and "governmental trust" are perceived differently in states with better executive constraints.

\section{Robustness tests}

We check the robustness of our findings in three ways. First, we insert alternative control variables in place of some control variables used in our main models to ensure that we indeed capture the desired notions of the indicators used in our models. For instance, we replace the educational attainment variable with a "postindustrialism index". 64 The post-industrialism index classifies countries into three categories: agrarian societies, industrial societies, and post-industrial societies. This index is highly and positively correlated with the educational attainment variable, in which post-industrial societies have the highest levels of educational attainment. Replacing the education variable with this index does not affect our main statistical results. Similarly, inserting an ordinal federalism index ${ }^{65}$ (which ranks between 1 and 5, 5 being the highest level of unitary state) instead of our federalism dummy variable does not alter our results. Furthermore, replacing the majoritarian electoral institution dummy variable with an ordinal variable for the proportionality of the election of the members of the lower houses does not affect our results. ${ }^{66}$

Second, we introduce further control variables that may affect political trust. Specifically, in line with the cultural approaches to political trust, ${ }^{67}$ we introduce dummy variables for major religions throughout the world to see whether certain religious cultures lead to different levels of political trust. ${ }^{68}$ When introduced into our models, none of the religion dummy variables (for Protestantism, Catholicism, and Islam) change our major findings. Statistically, nations with predominant Protestant or Muslim populations tend to trust more in political institutions whereas Catholic nations tend to have less political trust. A further discussion of the impact of different religions on political trust is beyond the scope of this article. 
In addition to the impact of religion variables, we also consider the effects of corruption on political trust. Scholars highlight the corrosive effect of corruption on political trust. $^{69}$ To account for the effects of corruption, we introduce the "political corruption index" (v2x_corr) from the V-Dem dataset ${ }^{70}$ into our models. This is an aggregate index, which measures the pervasiveness of corruption in the public sector and three branches of the government (lower values represent lower levels of corruption). The problem about this variable is high multicollinearity between our major explanatory variable (executive constraints variable) and the corruption variable. The correlation between these two variables is -0.77 , meaning there is very high correlation between executive constraints and corruption. Including each variable separately in the difference model yields statistically significant coefficients both for the executive constraints and the corruption variable (though our executive constraints variable has higher statistical significance based on the $t$-scores and $p$-values). Yet, introducing these two variables at the same time renders both insignificant, indicating multicollinearity. This indicates that executive constraints better operate in non-corrupt societies and where corruption erodes these constraints, citizens will hold similar (and lower) trust judgements regarding governmental and regulative state institutions. However, the effects of executive constraints on different elements of political trust go beyond the corruption arguments. Citizens' trust vested in regulative state institutions would not fluctuate with ups and downs in trust vested in governmental institutions based on their political and economic performance so long as there are institutionalized constraints on the executive. Higher statistical significance for the executive constraints variable in our major difference model corroborates this point. Hence, due to these reasons, we have decided to retain our main explanatory variable (executive constraints variable) in our models and keep the corruption variable out of the statistical analyses.

Finally, as we have done at the beginning of the article, we divide our sample into two groups: free and partly free countries and run our regressions for each group. The results (available upon request) show that the major linkage between executive constraints and political trust variables is stronger for free countries than partly free countries (though still strong in partly free countries). Better institutionalized checks and balances lead to higher levels of both regulative state trust and governmental trust in free countries. On the other hand, our executive constraints variable is stronger in our difference model for the subsample of the partly free states, as compared to free states. In other words, checks and balances more heavily affect the divergence of different components of political trust in our partly free countries subsample. All in all, the relationship between executive constraints and political trust holds both for free and partly free states.

\section{Conclusion}

This study has shown that the correlation between governmental trust and trust in regulative state institutions is lower in countries with better institutionalized checks and balances. In other words, the better executive constraints are institutionalized, the less trust in regulative state institutions fluctuates with governmental trust. ${ }^{71}$ A possible explanation for this relationship can be found in the existing literature on executive constraints. Cox and Weingast, for example, show that executive constraints are vital not only for the quality of democracy, but also for economic prospects. In light of a panel data from 1850 to 2005 , they demonstrate that increased executive constraints 
significantly reduce economic downturns and foster economic growth. ${ }^{72}$ Moreover, Henisz maintains that increased checks on the executive reduce political volatility since they "minimize the ability of politicians to respond to short-term political or social incentives to favour one group over another or transfer resources from society to the public sector". ${ }^{73}$ Taken together, these studies show that better performance and less volatility in public institutions due to less interference based on short-term political motives can explain our findings.

Given the central role of trust for political systems as discussed at the outset of this article, one could further argue for the indispensability of executive constraints for the prospects of stable and governable countries. As maintained earlier, the literature has established that effective policymaking, engagement in moral civic behaviour, cohesion of society, and the legitimacy and stability of democratic regimes strongly depend on citizens' trust in political institutions. ${ }^{74}$ This article has underlined that better executive checks are strongly correlated with fewer fluctuations of public trust in regulative state institutions. Considering the vital functions of public trust in state institutions regarding their governability and stability and nations' economic affluence, maintaining the autonomy of regulative state institutions stands crucial to help ensure a more governable, stable, and prosperous nation - even though such autonomy might come as a nuisance for some political leaders and groups.

\section{Notes}

1. Miller and Listhaug, "Political Parties and Confidence in Government"; Dalton, Democratic Challenges, Democratic Choices; Dalton and Weldon, "Public Images of Political Parties"; Della Porta, "Democracy and Distrust"; Norris, Democratic Deficit; McLaren, "The Cultural Divide in Europe"; Zmerli, "Social Structure and Political Trust in Europe"; Hooghe and Marien, "A Comparative Analysis of the Relation Between Political Trust and Forms of Political Participation"; Bauer and Fatke, "Direct Democracy and Political Trust"; Ignazi, "Power and the (Il)legitimacy of Political Parties."

2. Adams, Ezrow, and Somer-Topcu, "Do Voters Respond to Party Manifestos?"; Dalton and Weldon, "Public Images of Political Parties"; Della Porta, "Democracy and Distrust"; Hooghe and Marien, "A Comparative Analysis of the Relation Between Political Trust and Forms of Political Participation"; Ignazi, "Power and the (Il)legitimacy of Political Parties."

3. Levi and Stoker, "Political Trust and Trustworthiness"; Bouckaert and Van de Walle, "Comparing Measures of Citizen Trust"; Turper and Aarts, "Political Trust and Sophistication"; McLaren, "The Cultural Divide in Europe"; Zmerli, "Social Structure and Political Trust in Europe."

4. Van der Meer and Dekker, "Trustworthy States, Trusting Citizens?," 95.

5. Rosanvallon, Counter-Democracy, 8; Bouckaert and Van de Walle, "Comparing Measures of Citizen Trust," 333; Hooghe and Marien, "A Comparative Analysis of the Relation Between Political Trust and Forms of Political Participation," 133; see also Dalton, Democratic Challenges, Democratic Choices; Della Porta, "Democracy and Distrust"; Marien, "Measuring Political Trust Across Time and Space."

6. Marien, "Measuring Political Trust Across Time and Space," 17.

7. Bouckaert and Van de Walle, "Comparing Measures of Citizen Trust," 339; Zmerli, "Social Structure and Political Trust in Europe," 112; See also, Levi and Stoker, "Political Trust and Trustworthiness"; McLaren, "The Cultural Divide in Europe."

8. For a selection of studies which use a single additive index for political trust, see Mishler and Rose, "What are the Origins of Political Trust?"; Anderson and Singer, "The Sensitive Left and the Impervious Right"; Newton and Zmerli, "Three Forms of Trust"; Hooghe and Marien, "A Comparative Analysis of the Relation Between Political Trust and Forms of Political Participation"; Marien, "Measuring Political Trust Across Time and Space"; McLaren, "The Cultural Divide in Europe." 
9. Norris, Critical Citizens.

10. DeVellis, Scale Development, 109-110.

11. Hakhverdian and Mayne, "Institutional Trust, Education, and Corruption"; Hooghe and Marien, "A Comparative Analysis of the Relation Between Political Trust and Forms of Political Participation."

12. Turper and Aarts, "Political Trust and Sophistication."

13. Dalton and Weldon, "Public Images of Political Parties"; Zmerli, "Social Structure and Political Trust in Europe"; Bauer and Fatke, "Direct Democracy and Political Trust."

14. Dalton, Democratic Challenges, Democratic Choices.

15. Schneider, "Can We Trust Measures of Political Trust?"

16. Denters, Gabriel, and Torcal, "Political Confidence in Representative Democracies."

17. Torcal, "Political Trust in Western and Southern Europe."

18. Mishler and Rose, "What are the Origins of Political Trust?"; Dalton, Democratic Challenges, Democratic Choices; McLaren, "The Cultural Divide in Europe"; Bauer and Fatke, "Direct Democracy and Political Trust."

19. Easton, "A Re-assessment of the Concept of Political Support."

20. Zmerli, "Social Structure and Political Trust in Europe."

21. For a similar argument, see McLaren, "The Cultural Divide in Europe." We should note that according to Easton ("A Re-assessment of the Concept of Political Support") all political institutions present at the same time depend on specific and diffuse support. However, performative political institutions such as government should depend more on specific support, which is based on citizens' assessments of political institutions' performance such as ensuring good governance and economic growth, whereas trust in regulative state institutions more heavily depends on longer time horizons, showing more stable attitudes than performative representative political institutions.

22. Miller and Listhaug, "Political Parties and Confidence in Government," 385; Marien, "Measuring Political Trust Across Time and Space," 36.

23. For other papers questioning the unidimensionality of political trust in European countries, see Denters, Gabriel, and Torcal, "Political Confidence in Representative Democracies"; and Torcal, "Political Trust in Western and Southern Europe." As Godefroidt et al. argue, we need more "comparative, representative, comprehensive, and longitudinal studies beyond the established democracies" to understand the determinants of trust. Godefroidt, Langer, and Meuleman, "Developing Political Trust in a Developing Country," 919.

24. The first WVS wave was published in 1981-1984, the second in 1990-1994, the third in 19951999, the fourth in 2000-2004, the fifth in 2005-2009, the sixth in 2010-2014. All of the WVS can be found at http://www.worldvaluessurvey.org/WVSOnline.jsp.

25. The other options in the WVS waves regarding the trust (confidence) in governmental and state institutions are "not very much," "none at all," and "no answer." "No answer" responses are negligible for all of the countries included in the dataset, hovering around $1 \%$ (below in almost all cases).

26. Marien, "Measuring Political Trust Across Time and Space"; Schneider, "Can We Trust Measures of Political Trust?"

27. We should underline that the existence and relative weights of different notions such as transparency, participation, efficacy, and satisfaction with service delivery regarding the conceptualization of political trust under democratic versus authoritarian settings need to be seen in a continuum. It is true that satisfaction with service delivery is crucial in all regime types, democratic or not. In a similar vein, citizens in authoritarian countries may also desire political accountability and transparency, yet it is hard to capture those sentiments due to preference falsification. All in all, rather than their total existence or lack thereof, each sub-notion about political trust has gradations under different political settings, which makes it harder to compare democratic versus authoritarian countries.

28. Aleman and Woods, "Value Orientations from the World Values Survey." In a cross-national study which combines democratic and authoritarian nations, Schneider ("Can We Trust Measures of Political Trust?") underlines that authoritarian countries appear to be the most trusting of government and have high factor loadings for both representative and regulative political institutions (that is, citizens tend to conflate these institutions together in their trust judgements). While she argues that there are also differences among democratic nations (specifically 
between post-communist versus Western nations), this does not render cross-national comparisons among democratic nations impossible, whereas comparisons between democratic and authoritarian states are inappropriate as political institutions in these states have utterly different roles, functions, and trust judgements in the eyes of the citizens.

29. Kitschelt and Wilkinson, Patrons, Clients, and Policies.

30. Bouckaert and Van de Walle, "Comparing Measures of Citizen Trust."

31. Kuran, Private Truths, Public Lies; Wedeen, Ambiguities of Domination.

32. Rose, "Perspectives on Political Behavior"; Darden and Grzymala-Busse, "The Great Divide."

33. Jiang and Yang, "Lying or Believing?"

34. Freedom House categorizes countries under the labels of "free," "partly free," and "not free." One could argue that some of the problems associated with "not free" cases could also apply to "partly free" cases. To account for this possibility, we run robustness tests for "free" and "partly free" countries separately and we find that our hypothesized relationship between executive constraints and political trust hold for each group of countries separately (see section called Robustness Checks).

35. The countries that have experienced such transitions (from "partly free" to "not free" or vice versa) and that have been included in this study are Kyrgyzstan, Lebanon, Libya, Pakistan, Russia, and Tunisia. The article considers data for these countries if and only if these countries are considered at least "partially free" for the relevant time of the WVS survey.

36. Coppedge et al., Varieties of Democracy (V-Dem) Project.

37. Ibid., 46.

38. Criado and Herreros, "Political Support"; Mishler and Rose, "What are the Origins of Political Trust?"; Dalton, Democratic Challenges, Democratic Choices; McLaren, "The Cultural Divide in Europe"; Zmerli, "Social Structure and Political Trust in Europe."

39. Mishler and Rose, "What are the Origins of Political Trust?"

40. Freitag and Bühlmann, "Crafting Trust"; Kelleher and Wolak, "Explaining Public Confidence"; Dalton, Democratic Challenges, Democratic Choices; McLaren, "The Cultural Divide in Europe"; Zmerli, "Social Structure and Political Trust in Europe."

41. Freitag and Bühlmann, "Crafting Trust," 1545.

42. Zmerli, "Social Structure and Political Trust in Europe."

43. Anderson and Singer, "The Sensitive Left and the Impervious Right"; Freitag and Bühlmann, "Crafting Trust"; Turper and Aarts, "Political Trust and Sophistication."

44. Seligson, "The Impact of Corruption on Regime Legitimacy."

45. Hakhverdian and Mayne, "Institutional Trust, Education, and Corruption."

46. Turper and Aarts, "Political Trust and Sophistication," 3-4.

47. Inglehart, Modernization and Postmodernization; Norris, Democratic Deficit; Dalton, Democratic Challenges, Democratic Choices.

48. Zmerli, "Social Structure and Political Trust in Europe," 112.

49. Barro and Lee, "A New Data Set of Educational Attainment."

50. Anderson et al., Losers' Consent; Van der Meer and Dekker, "Trustworthy States, Trusting Citizens?"

51. Freitag and Bühlmann, "Crafting Trust."

52. Norris, Critical Citizens.

53. Criado and Herreros, "Political Support," 1512.

54. Norris, Critical Citizens, 223.

55. Norris, Democracy Time-series Dataset.

56. Elazar, "Contrasting Unitary and Federal Systems."

57. Norris, Critical Citizens; Criado and Herreros, "Political Support."

58. Delhey and Newton, "Predicting Cross-National Levels of Social Trust."

59. Alesina et al., "Fractionalization."

60. Haggard and Kaufman, "The Political Economy of Democratic Transitions."

61. Fairbrother, "Two Multilevel Modeling Techniques," 119-121.

62. Baltagi, Econometric Analysis; Gelman and Hill, Data Analysis.

63. Hoechle, "Robust Standard Errors."

64. Norris, Democracy Time-series Dataset, "cosmopolitan index."

65. Ibid. 
66. This variable is based on Norris's (Democracy Time-series Dataset) housesys variable but is an updated and corrected version. Our housesys variable is 1 when all (or nearly all) members of the lower house are elected by a PR system, 0 if they are elected by majoritarian rule, and 0.5 if there is a mixed (PR plus majoritarian) half-and-half election of members. Countries which have a mixed procedure of election of the lower house members that approximates to a 50-50 distribution are also counted as 0.5 (for example, Georgia has 77 lower house members elected by PR and 73 by majoritarian; Lithuania, 71 to 70 ; Hungary 152 to 176).

67. Inglehart, Modernization and Postmodernization.

68. Cf. Norris, Democracy Time-series Dataset.

69. Mishler and Rose, "What are the Origins of Political Trust?," 48; Freitag and Bühlmann, "Crafting Trust," 1537 and 1554; Van der Meer and Dekker, "Trustworthy States, Trusting Citizens?"; McLaren, "The Cultural Divide in Europe," 210; Van Meer and Hakhverdian, "Institutional Trust, Education, and Corruption," 89.

70. Coppedge et al., Varieties of Democracy (V-Dem) Project.

71. Our results support the recent findings on the institutional sources of political trust. See for example, Godefroidt, Langer, and Meuleman, "Developing Political Trust in a Developing Country"; and Baum, "The Impact of Bureaucratic Openness on Public Trust in South Korea."

72. Cox and Weingast, "Executive Constraint, Political Stability and Economic Growth."

73. Henisz, "Political Institutions and Policy Volatility," 6.

74. Levi and Stoker, "Political Trust and Trustworthiness"; Bouckaert and Van de Walle, "Comparing Measures of Citizen Trust"; Turper and Aarts, "Political Trust and Sophistication"; McLaren, "The Cultural Divide in Europe"; Zmerli, "Social Structure and Political Trust in Europe."

\section{Disclosure statement}

No potential conflict of interest was reported by the authors.

\section{Notes on contributors}

Kursat Cinar earned his $\mathrm{PhD}$ in Political Science from Ohio State University. His research interests centre on party politics, democratization, patron-client relationships, development, and gender politics. He has published in Politics \& Gender, Political Studies, Democratization, Contemporary Politics, Mediterranean Politics, Journal of Balkan and Near Eastern Studies, and Turkish Studies. Kursat Cinar's book titled Departing Democracy: The Rise of Hegemonic Party Rule in Turkey and Beyond will be published by the University of Michigan Press. A chapter written by Cinar on clientelism has recently appeared in the Sage Encyclopedia of Political Behavior. Dr Cinar is Fulbright and EU Marie Curie Alumnus and the recipient of the 2013 Sabanci International Research Award. He is also an Associate Editor of Politics \& Gender. He is currently an Assistant Professor in Middle East Technical University's Department of Political Science \& Public Administration.

Meral Ugur-Cinar received her PhD in Political Science from the University of Pennsylvania in 2012. She was a Mellon Interdisciplinary Postdoctoral Fellow at the New School for Social Research in 20122013. Her research interests include political institutions, democracy, citizenship, collective memory, social movements, and gender. Her articles have appeared in PS: Political Science \& Politics, Political Studies, Politics \& Gender, Political Quarterly, Middle Eastern Studies, British Journal of Middle Eastern Studies, Mediterranean Studies, and Turkish Studies. A chapter she co-authored with Rogers Smith can be found in Political Peoplehood: The Roles of Values, Interests and Identities (Chicago University Press). Her book titled Collective Memory and National Membership: Identity and Citizenship Models in Turkey and Austria is published by Palgrave. Dr Ugur-Cinar is currently an Assistant Professor at Bilkent University, Ankara, Turkey.

\section{ORCID}

Kursat Cinar (D) http://orcid.org/0000-0001-6044-2810

Meral Ugur-Cinar (D) http://orcid.org/0000-0002-2195-4861 


\section{Bibliography}

Adams, J., L. Ezrow, and Z. Somer-Topcu. "Do Voters Respond to Party Manifestos or to a Wider Information Environment? An Analysis of Mass-Elite Linkages on European Integration." American Journal of Political Science 58, no. 4 (2014): 967-978.

Aleman, J., and D. Woods. "Value Orientations from the World Values Survey: How Comparable Are They Cross-Nationally?” Comparative Political Studies 49, no. 8 (2016): 1039-1067.

Alesina, A., A. Devleeschauwer, W. Easterly, S. Kurlat, and R. Wacziarg. "Fractionalization." Journal of Economic Growth 8 (2003): 155-194.

Anderson, C. J., A. Blais, S. Bowler, and T. Donovan. Losers' Consent: Elections and Democratic Legitimacy. Oxford: Oxford University Press, 2005.

Anderson, C. J., and M. M. Singer. "The Sensitive Left and the Impervious Right: Multilevel Models and the Politics of Inequality, Ideology, and Legitimacy in Europe." Comparative Political Studies 41, no. 4/5 (2008): 564-599.

Baltagi, B. H. Econometric Analysis of Panel Data. West Sussex: Wiley, 2008.

Barro, R., and J. Lee. “A New Data Set of Educational Attainment in the World, 1950-2010." Journal of Development Economics 104 (2013): 184-198.

Bauer, P., and M. Fatke. "Direct Democracy and Political Trust: Enhancing Trust, Initiating Distrust-or Both?" Swiss Political Science Review 20, no. 1 (2014): 49-69.

Baum, J. B. "The Impact of Bureaucratic Openness on Public Trust in South Korea." Democratization 16, no. 5 (2009): 969-997.

Bouckaert, G., and S. Van de Walle. "Comparing Measures of Citizen Trust and User Satisfaction as Indicators of 'Good Governance': Difficulties in Linking Trust and Satisfaction Indicators." International Review of Administrative Sciences 69 (2013): 329-343.

Coppedge, M., J. Gerring, S. Lindberg, S. Skaaning, J. Teorell, D. Altman, M. Bernhard, S. et al. 2016. Varieties of Democracy (V-Dem) Project, V-Dem Dataset v6.2.

Cox, G., and B. Weingast. "Executive Constraint, Political Stability and Economic Growth." Comparative Political Studies 51, no. 3 (2018): 279-303.

Criado, H., and F. Herreros. "Political Support: Taking Into Account the Institutional Context." Comparative Political Studies 40, no. 12 (2007): 1511-1532.

Dalton, R. Democratic Challenges, Democratic Choices: The Erosion of Political Support in Advanced Industrial Democracies. Oxford University Press, 2004.

Dalton, R., and S. Weldon. "Public Images of Political Parties: A Necessary Evil?" West European Politics 28 (2005): 931-951.

Darden, K., and A. Grzymala-Busse. “The Great Divide.” World Politics 59 (2006): 83-115.

Delhey, J., and K. Newton. "Predicting Cross-National Levels of Social Trust: Global Pattern or Nordic Exceptionalism?” European Sociological Review 21, no. 4 (2005): 311-327.

Della Porta, D. "Democracy and Distrust." Perspectives on Politics 8, no. 3 (2010): 890-892.

Denters, B., O. Gabriel, and M. Torcal. "Political Confidence in Representative Democracies: SocioCultural vs. Political Explanations." In Citizenship and Involvement in European Democracies: A Comparative Analysis, edited by J. W. Van Deth, J. R. Montero and A. Westholm, 66-87. London: Routledge, 2007.

DeVellis, R. F. Scale Development: Theory and Applications. Los Angeles: Sage, 2012.

Easton, D. "A Re-assessment of the Concept of Political Support." British Journal of Political Science 5, no. 4 (1975): 435-457.

Elazar, D. "Contrasting Unitary and Federal Systems." International Political Science Review 18, no. 3 (1997): 237-251.

Fairbrother, M. “Two Multilevel Modeling Techniques for Analyzing Comparative Longitudinal Survey Datasets." Political Science Research and Methods 2, no. 1 (2014): 119-140.

Freitag, M., and M. Bühlmann. "Crafting Trust: The Role of Political Institutions in a Comparative Perspective." Comparative Political Studies 42, no. 12 (2009): 1537-1566.

Gelman, A., and J. Hill. Data Analysis Using Regression and Multilevel/Hierarchical Models. Cambridge: Cambridge University Press, 2007.

Godefroidt, A., A. Langer, and B. Meuleman. "Developing Political Trust In A Developing Country: The Impact of Institutional and Cultural Factors on Political Trust in Ghana." Democratization 24, no. 6 (2017): 906-928. 
Haggard, S., and R. Kaufman. "The Political Economy of Democratic Transitions." Comparative Politics 29, no. 3 (1997): 263-283.

Hakhverdian, A., and Q. Mayne. "Institutional Trust, Education, and Corruption: A Micro-Macro Interactive Approach." The Journal of Politics 74, no. 3 (2012): 739-750.

Henisz, W. J. "Political Institutions and Policy Volatility." Economics and Politics 16, no. 1 (2004): 1-27.

Hoechle, D. "Robust Standard Errors for Panel Regressions with Cross-Sectional Dependence." Stata Journal 7, no. 3 (2007): 281-312.

Hooghe, M., and S. Marien. "A Comparative Analysis of the Relation Between Political Trust and Forms of Political Participation in Europe." European Societies 15, no. 1 (2013): 131-152.

Ignazi, P. "Power and the (Il)Legitimacy of Political Parties: An Unavoidable Paradox of Contemporary Democracy?" Party Politics 20, no. 2 (2014): 160-169.

Inglehart, R. Modernization and Postmodernization: Cultural, Economic, and Political Change in 43 Societies. Princeton, NJ: Princeton University Press, 1997.

Jiang, J., and D. L. Yang. "Lying or Believing? Measuring Preference Falsification From Political Purge in China." Comparative Political Studies 49, no. 5 (2016): 600-634.

Kelleher, C. A., and J. Wolak. "Explaining Public Confidence in the Branches of State Government." Political Research Quarterly 60, no. 4 (2007): 707-721.

Kitschelt, H., and S. I. Wilkinson. Patrons, Clients, and Policies: Patterns of Democratic Accountability and Political Competition. Cambridge: Cambridge University Press, 2007.

Kuran, T. Private Truths, Public Lies: The Social Consequences of Preference Falsification. Cambridge, MA: Harvard University Press, 1997.

Levi, M., and L. Stoker. "Political Trust and Trustworthiness." Annual Review of Political Science 3 (2000): 475-507.

Marien, S. "Measuring Political Trust Across Time and Space." In Political Trust, Why Context Matters, edited by M. Hooghe and S. Zmerli, 13-46. Colchester: ECPR Press, 2011.

McLaren, L. M. "The Cultural Divide in Europe: Migration, Multiculturalism, and Political Trust." World Politics 64, no. 2 (2012): 199-241.

Miller, A. H., and O Listhaug. "Political Parties and Confidence in Government: A Comparison of Norway, Sweden, and the United States." British Journal of Political Science 29 (1990): 357-386.

Mishler, W., and R. Rose. "What are the Origins of Political Trust? Testing Institutional and Cultural Theories in Post-Communist Societies." Comparative Political Studies 34, no. 1 (2001): 30-62.

Newton, K., and S. Zmerli. "Three Forms of Trust and Their Association." European Political Science Review 3, no. 2 (2011): 169-200.

Norris, P. Critical Citizens: Global Support for Democratic Government. Oxford: Oxford University Press, 1999.

Norris, P. Democracy Time-series Dataset. https://www.hks.harvard.edu/fs/pnorris/Data/Data.htm, 2009.

Norris, P. Democratic Deficit: Critical Citizens Revisited. Cambridge: Cambridge University Press, 2011.

Rosanvallon, P. Counter-Democracy: Politics in an Age of Distrust. Cambridge: Cambridge University Press, 2008.

Rose, R. "'Perspectives on Political Behavior in Time and Space." In Oxford Handbook of Political Behavior, edited by R. J. Dalton and H.-D. Klingemann, 283-301. Oxford, UK: Oxford University Press, 2007.

Schneider, I. "Can We Trust Measures of Political Trust? Assessing Measurement Equivalence in Diverse Regime Types." Social Indicators Research 133 (2017): 963-984.

Seligson, M. "The Impact of Corruption on Regime Legitimacy: A Comparative Study of Four Latin American Countries." Journal of Politics 64, no. 2 (2002): 408-433.

Torcal, M. "Political Trust in Western and Southern Europe." In Handbook on Political Trust, edited by S. Zmerli and T. Van der Meer, 418-439. Cheltenham: Edward Elgar Publishing, 2017.

Turper, S., and K. Aarts. 2015. "Political Trust and Sophistication: Taking Measurement Seriously". Social Indicators Research. Published Online. doi:10.1007/s11205-015-1182-4.

Van der Meer, T., and P. Dekker. "Trustworthy States, Trusting Citizens? A Multi-Level Study into Objective and Subjective Determinants of Political Trust." In Political Trust - Why Context Matters: Causes and Consequences of a Relational Concept, edited by M. Hooghe and S. Zmerli, 95-116. Colchester: ECPR Press, 2011.

Van der Meer, T., and A. Hakhverdian. "Political Trust as the Evaluation of Process and Performance: A Cross-National Study of 42 European Countries.” Political Studies 65, no. 1 (2017): 81-102. 
Wedeen, L. Ambiguities of Domination: Politics, Rhetoric, and Symbols in Contemporary Syria. Chicago, IL: University of Chicago Press, 1999.

Zmerli, S. "Social Structure and Political Trust in Europe." In Society and Democracy in Europe, edited by O. W. Gabriel and S. Keil, 111-138. London: Routledge, 2012.

\section{Appendix A - Descriptive statistics}

\begin{tabular}{lccccc}
\hline & Mean & Median & Min & Max & Std. deviation \\
\hline Dependent Variables: & & & & & \\
Regulatory State Trust & 48.09 & 49.35 & 9.90 & 79.70 & 15.03 \\
Governmental Trust & 40.72 & 40.30 & 7.70 & 86.50 & 15.23 \\
$\begin{array}{l}\text { RegvsGov } \\
\text { Independent Variables: }\end{array}$ & 6.93 & 7.10 & -21.2 & 34.8 & 13.23 \\
$\begin{array}{l}\text { Explanatory Variable } \\
\text { Executive Constraints }\end{array}$ & & & & & \\
Control Variables & 0.70 & 0.76 & 0.07 & 0.97 & 0.22 \\
GDP Growth & & & & & \\
Gini Index & 2.43 & 3.20 & -30.9 & 33.7 & 5.51 \\
Educational Attainment & 38.06 & 35.40 & 19.00 & 65.00 & 9.63 \\
Majoritarian Electoral Institution & 8.22 & 8.65 & 2.6 & 13.4 & 2.82 \\
Regime Type & 0.59 & 1.00 & 0.00 & 1.00 & 0.49 \\
Federal vs. Unitary States & 0.98 & 1.00 & 0.00 & 2.00 & 0.94 \\
Ethnolinguistic Fractionalization & 0.60 & 1.00 & 0.00 & 1.00 & 0.48 \\
Military Coup Dummy & 0.39 & 0.40 & 0.00 & 0.85 & 0.23 \\
\hline
\end{tabular}

